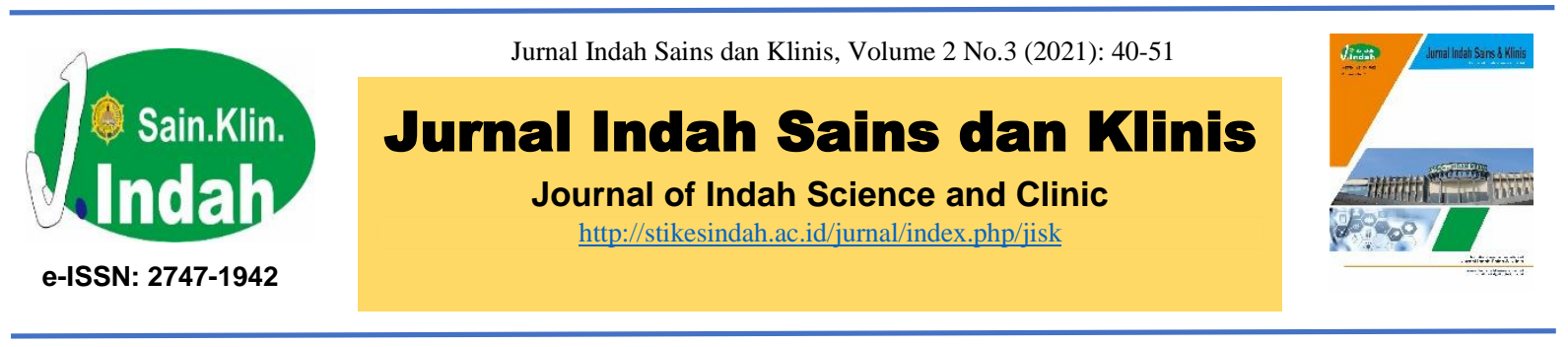

\title{
Pengaruh Perawatan Luka Menggunakan Gel Lidah Buaya terhadap Kesembuhan Dekubitus
}

\author{
Erika $^{1)}$, Rahma Fridayana Fitri ${ }^{2)}$ Ainyia Sumiati ${ }^{3)}$ \\ ${ }^{1}$ STIKES Indah Medan, Jl. Saudara Ujung No. 110, Medan, pasariburika@ stikesindah-medan.ac.id; Universitas \\ Sumatera Utara, J1. Dr. Mansyur No. 35, Medan, rahmafridayana@gmail.com; STKes Indah Medan, Jl. Saudara \\ Ujung No. 110, Medan, ainyiasumiati@gmail.com; Corresponding author: pasariburika@stikesindah-medan.ac.id
}

Received: 24 Oktober 2021; Revised: 29 Nopember 2021; Accepted: 1 Desember 2021

DOI: $10.52622 /$ jisk.v2i3.35

\begin{abstract}
Decubitus has recently become a problem in both developed and developing countries, especially Indonesia. Until now, pressure sores are still a classic problem in the health sector, especially in the nursing field. In Kebumen Hospital, 38.18\% of patients had pressure sores. Damage to skin integrity caused by bed rest, if left unchecked for a long time will irritate the skin until the formation of wounds on the skin, therefore tissue undergoing necrosis due to lack of blood supply to certain tissues. Nowadays, this is a secondary affliction experienced by many hospitalized patients. This paper aims to determine the effect of wound care using aloe vera gel on the healing of decubitus performed on 10 people in Tanjung Rejo Village, Percut Sei Tuan, Deli Serdang.This study used an experimental method by looking at the cure rate given by aloe vera gel and before being given aloe vera gel, moreover, for the response given aloe vera gel and not. Based on the output of the Mann-Whitney test, it is known that the p-value is $0.008<(\alpha=0.05)$, so it can be concluded that there is a difference between the control group and the treatment group. Because there is a significant difference, it can be assumed that there is an effect of giving aloe vera gel on the healing process of decubitus wounds.
\end{abstract}

Keywords: Aloe Vera, Decubitus, Treatment, Wound

\begin{abstract}
Abstrak
Dekubitus pada akhir-akhir ini sudah menjadi sebuah problem baik di Negara maju maupun Negara dalam tahap berkembang, khususnya Indonesia. Hingga saat ini luka dekubitus masih merupakan masalah yang klasik pada bidang kesehatan terutama bidang keperawatan. Di RSUD Kebumen didapatkan 38.18\% pasien mengalami dekubitus. Kerusakan integritas kulit yang disebabkan oleh tirah baring ini, jika dibiarkan lama kelamaan akan menimbulkan iritasi pada kulit sampai terbentuknya luka pada kulit akibat dari jaringan yang mengalami nekrosis karena kurangnya suplai darah kejaringan tertentu. Bahkan sekarang hal ini merupakan suatu penderitaan sekunder yang banyak dialami oleh pasien-pasien yang dirawat di rumah sakit. Tulisan ini bertujuan untuk mengetahui pengaruh perawatan luka menggunakan gel lidah buaya (aloe vera) terhadap kesembuhan decubitus yang dilakukan kepada 10 orang di Desa Tanjung Rejo Kecamatan Percut Sei Tuan, Deli Serdang. Penelitian ini menggunakan metode eksperimental dengan melihat tingkat
\end{abstract}


kesembuhan yang diberikan gel lidah buaya dan sebelum diberikan gel lidah buaya, untuk respon yang dihasilkan pada sampel yang diberikan gel lidah buaya dan yang tidak diberikan gel lidah buaya. Berdasarkan output uji Mann Whitney diketahui bahwa p value 0,008 $<\alpha(\alpha=0,05)$ maka dapat di simpulkan bahwa ada perbedaan antara kelompok kontrol dengan kelompok perlakuan. Karena ada perbedaan yang signifikan maka dapat disimpulkan bahwa ada pengaruh pemberian gel lidah buaya (aloe vera) terhadap proses penyembuhan luka decubitus.

Kata kunci: Aloe Vera, Dekubitus, Perawatan, Luka

\section{PENDAHULUAN}

Dekubitus adalah kerusakan atau kematian kulit sampai jaringan di bawah kulit, bahkan menembus otot sampai mengenai tulang akibat adanya penekanan pada suatu area secara terus menerus sehingga mengakibatkan gangguan sirkulasi darah setempat. Ulkus dekubitus sering disebut sebagai ischemic ulcer, Pressure Ulcer, Pressure sore, bed sore, decubital ulcer (1).

Kejadian dekubitus (luka tekan) diseluruh dunia di intensive care unit (ICU) berkisar 1\% - 56\%. Selanjutnya, dilaporkan juga dari prevalensi luka tekan yang terjadi di ICU dari Negara dan benua lain yaitu 49\% di Eropa, 22\% di Amerika Utara, 50\% di Australia. Sedangkan prevalensi kejadian dekubitus pada pasien stroke berdasarkan penelitian yang dilakukan oleh Langhorne di inggris mencapai 29\%. Di Korea khusus - nya di ICU kejadian luka tekan meningkat dari 10,5\% - 45\%. Di Indonesia, kejadian luka tekan pada pasien yang dirawat di ICU mencapai 33\%. Angka ini sangat tinggi bila dibandingkan dengan angka luka tekan di Asia Tenggara yang berkisar 2,1\% - 31,3\%. Penyebab utama dari luka tekan adalah tekanan dan toleransi jaringan. Tekanan yang berkepanjangan merupakan penyebab utama luka tekan karena tekanan dapat menyebabkan insufisiensi aliran darah, anoreksia, dan iskemia jaringan lunak (2).

Dekubitus pada akhir-akhir ini sudah menjadi sebuah problem baik di Negara maju maupun Negara dalam tahap berkembang, khususnya Indonesia. Hingga saat ini luka dekubitus masih merupakan masalah yang klasik pada bidang kesehatan terutama bidang keperawatan. Di RSUD Kebumen didapatkan 38.18\% pasien mengalami dekubitus. Kerusakan integritas kulit yang disebabkan oleh tirah baring ini, jika dibiarkan lama kelamaan akan menimbulkan iritasi pada kulit sampai terbentuknya luka pada kulit akibat dari jaringan yang mengalami nekrosis karena kurangnya suplai darah kejaringan tertentu. Bahkan sekarang hal ini merupakan suatu penderitaan sekunder yang banyak dialami oleh pasien-pasien yang dirawat di rumah sakit. Luka merupakan masalah yang sering dialami tiap orang dan sering kali dianggap ringan, padahal luka itu dapat menimbulkan infeksi. Dalam upaya mencegah infeksi tersebut dibutuhkan obat luka. Obat luka yang ada bermacam-macam, diantaranya yang sering dipakai adalah iodium providon yang masih mempunyai efek samping yaitu iritasi pada pasien yang hipersensitif (3).

Depkes melakukan penelitian dan hasil menunjukkan bahwa 6,5-9,4\% dari populasi umum orang dewasa yang dirawat di RS, menderita paling sedikit satu dekubitus pada setiap kali masuk RS. Upaya pengobatan terhadap dekubitus dimulai sejak Perang Dunia II dan sampai saat ini meskipun pencegahan dan pengobatan dekubitus telah diteliti secara luas lebih dari 30 tahun, hanya terdapat sedikit bukti yang menunjukkan adanya penurunan insiden decubitus (1).

Luka dekubitus adalah suatu masalah endemic bagi populasi pasien yang dirawat di rumah atau rumah perawatan lainnya. Pasien-pasien tersebut memiliki resiko untuk mengalami terjadinya luka dekubitus selama perawatan. Penelitian menunjukkan bahwa prevalensi luka dekubitus bervariasi, tetapi secara umum dilaporkan bahwa 5\% sampai $11 \%$ terjadi di tatanan perawatan akut (acute care), 15\% sampai $25 \%$ di tatanan perawatan jangka - panjang (longterm care), dan 7\% sampai 12\% di tatanan perawatan rumah (home health care) $(2,4)$.

Luka dekubitus dibagi menjadi empat derajat, derajat 1 yaitu ada perubahan dari kulit yang dapat diobservasi, hanya meliputi lapisan kulit terluar saja, kulit masih utuh, luka tampak kemerahan dengan warna kulit putih atau berwarna lebih gelap pada orang dengan kulit gelap, kulit yang terkena dapat terasa lebih nyeri, lunak, panas atau terasa lebih dingin dibandingkan dengan kulit sekitarnya. Derajat 2 yaitu luka terbuka, Lapisan terluar kulit (epidermis) dan lapisan di bawah nya (dermis) mengalami kerusakan, dapat berbentuk luka terbuka seperti kawah dangkal dengan ada cairan di dalamnya. Cirinya adalah lukanya 
superficial, abrasi, melepuh, atau membentuk lubang yang dangkal. Jika kulit terluka atau robek maka akan timbul masalah baru, yaitu infeksi. Derajat 3 yaitu hilangnya kulit secara lengkap meliputi kerusakan atau nekrosis dari jaringan subkutan atau lebih dalam, tapi tidak sampai pada fascia. Derajat 4 yaitu hilangnya lapisan kulit yang lengkap dengan kerusakan yang luas, nekrosis jaringan, kerusakan otot tulang dan tendon. Unstageable, pada klasifikasi ini ditemukan hilangnya seluruh jaringan yang mana dasar ulkus ditutupi oleh slough (kuning, cokelat, abu-abu, hijau atau coklat) dan /atau eschar atau jaringan nekrotik (cokelat, cokelat atau hitam) di sekitar luka. Dikatakan klasifikasi yang unstageable oleh karena luka ditutupi oleh slough dan eschar yang sehingga tidak dapat menilai bagaimana dasar luka dan kedalaman lukanya. Suspected deep tissue injury, pada daerah sekitar luka dapat ditemukan adanya perubahan warna berupa ungu atau merah marun dari kulit yang utuh dikarenakan adanya kerusakan jaringan lunak yang mendasari dari tekanan (5).

Kesembuhan pada ulkus dekubitus dapat dipengaruhi berbagai faktor diantaranya: Mengganti posisi penderita untuk miring kanan dan kiri setidaknya setiap 2 jam sekali. Menggunakan alat bantu seperti bantal busa lunak untuk mengurangi tekanan pada kulit, menjaga kulit tetap bersih dan kering, bisa digunakan bedak untuk kulit yang rentan terkena gesekan dan menjaga asupan makanan bergizi dan cukup minum. Selain daripada itu pencegahan terjadinya dekubitus bisa dengan melakukan perawatan kulit yaitu dengan menjaga kulit agar tetap bersih dan lembab, menggunakan pembersih kulit dengan $\mathrm{pH}$ yang seimbang melindungi kulit dari paparan kelembaban yang berlebihan dengan memberikan topikal untuk mengurangi risiko kerusakan tekanan.

Selain dari itu untuk pengobatan ulkus dekubitus di Rumah Sakit dilakukan dengan cara membersihkan luka dan menempatkan dressing/pembalut pada luka, perawatan luka dengan mengganti pembalut secara teratur, mengurangi tekanan pada luka denggan cara mengubah posisi dan menggunakan papan pendukung, penggunaan antibiotik untuk pengobatan infeksi, pengobatan nyeri untuk meringankan gejala, pembedahan untuk membuang jaringan yang sudah mati dari luka, pengaturan gizi dan meningkatkan asupan cairan untuk penyembuhan yang lebih cepat (6).

Maka dari itu luka tekan (decubitus) merupakan contoh jenis luka kronis dimana biaya penyembuhan terhadap luka tersebut terbilang mahal. ${ }^{7}$ Penggunaan tumbuhan merupakan cara alternatif yang tepat untuk pengobatan terhadap luka kronis decubitus. Salah satu diantara berbagai tumbuhan obat yang diketahui berkhasiat bagi kesehatan yaitu lidah buaya (Aloe vera). Dengan berbagai komponen yang terkandung didalamnya, lidah buaya diketahui dapat mempengaruhi penyembuhan luka kronis decubitus. Semakin meningkatnya minat kembali ke alam (back to nature) ditambah krisis moneter dimana obat medis semakin mahal membuat masyarakat mencari pengobatan tradisional sebagai alternative, ditambah semakin meningkatnya kemajuan di bidang teknik isolasi dan instrumentasi untuk analisis. Salah satu diantara berbagai tumbuhan obat yang diketahui berkhasiat bagi kesehatan yaitu lidah buaya $(1,8,9)$.

Penelitian sebelumnya tahun 2015 dengan sampel menggunakan tikus putih strain wistar berjenis kelamin betina, berat 150 - 250 gr dan usia 2, 5 - 3 bulan dengan hasil penelitian menunjukkan bahwa ada perbedaan efek dari berbagai konsentrasi ekstrak daun lidah buaya (Aloe vera) terhadap diameter penyembuhan luka kronis decubitus pada tikus putih dan konsentrasi ekstrak daun lidah buaya (Aloe vera) $100 \%$ dapat memberikan pengaruh yang paling baik terhadap diameter penyembuhan luka kronis decubitus pada tikus putih $(a ́=0,05)(10)$. Berdasarkan studi pendahuluan yang dilakukan pada bulan Januari 2021 ternyata masih ada masyarakat yang menderita penyakit ulkus dekubitus, dan didapatkan 10 orang yang menderita penyakit ulkus dekubitus, dari ke sepuluh pasien tersebut belum pernah dilakukan perawatan luka menggunakan gel lidah buaya di Desa Tanjung Rejo Kec. Percut Sei Tuan, Deli Serdang.

\section{METODE PENELITIAN}

Penelitian ini menggunakan metode eksperimental dengan dengan melihat tingkat kesembuhan yang diberikan gel lidah buaya dan sebelum diberikan gel lidah buaya, untuk respon yang dihasilkan pada sampel yang diberikan gel lidah buaya dan yang tidak diberikan gel lidah buaya. ${ }^{11}$ Populasi dalam penelitian ini adalah semua penderita dekubitus di Desa Tanjung Rejo Kec. Percut Sei Tuan, Deli Serdang dari bulan Juli sampai bulan Oktober tahun 2021 yang berjumlah 10 orang yang diperoleh dari jumlah populasi menggunakan teknik sampling jenuh. ${ }^{12}$ Proses pengumpulan data pada penelitian ini dengan cara mencari 
penderita dekubitus di Desa Tanjung Rejo Kec. Percut Sei Tuan, Deli Serdang dengan hanya memilih penderita dekubitus yang memiliki riwayat penyakit DM. Dan untuk jenis instrumen dalam penelitian ini menggunakan lembar observasi.

Kelompok eksperimental diberi perlakuan yaitu dilakukan perawatan luka dekubitus menggunakan gel lidah buaya, sedangkan kelompok kontrol diberi perlakuan dengan larutan $\mathrm{NaCl}$ 0,9\%. Pada dua kelompok ini di lalui dengan pengukuran (observasi luka) pra test.

Perawatan yang di lakukan pada penderita dekubitus dengan menggunakan gel lidah buaya sebagai bahan dalam tehnik perawatan luka dengan cara luka dekubitus di bersihkan menggunakan cairan $\mathrm{NaCl}$ 0,9\% dan sesuai dengan SOP perawatan luka dekubitus, setelah luka di bersihkan maka luka tersebut akan diberi gel lidah buaya dengan cara dioleskan pada luka lalu di balut dengan kasa, perawatan di lakukan sekali dalam sehari.

Tingkat penyembuhan luka dekubitus pasien yang dinilai dari Proses penghentian perdarahan (hemostasis), Proses peradangan (inflamasi), Proses pembangunan jaringan baru (proliferasi), Proses penguatan jaringan ( maturasi ) yang diamati secara klinis pada minggu ke - 1, minggu ke - 2, minggu ke 3, dan minggu ke - 4 menggunakan alat ukur untuk mengukur luka yang di bandingkan antara kelompok eksperimen dengan kelompok kontrol.

Dalam penelitian ini menggunakan Instrumen pengukuran luka yaitu skala Bates Jensen Wound Assessment Tool (BJWAT). Instrumen pengukuran luka yang terdiri dari 13 item pertanyaan yang meliputi ukuran, kedalaman, tepi luka, undermining, jenis jaringan nekrotik, jumlah nekrotik, granulasi dan jaringan epitelisasi, jenis dan jumlah eksudat, warna kulit sekitarnya, edema, dan indurasi luka. Instrument ini dinilai menggunakan skala Likert yang telah dimodifikasi yaitu: skor 1 menunjukkan sehat dan 5 menunjukkan atribut yang paling tidak sehat untuk setiap karakteristik. Observasi penilaian perkembangan luka dilakukan pada awal penelitian dan akhir penelitian. Berikut ini instrumen BJWAT:

1. Ukuran luka
a) $1=\mathrm{P} \times \mathrm{L}<4 \mathrm{~cm}$
b) $2=\mathrm{P} X \mathrm{~L}<16 \mathrm{~cm}$
c) $3=\mathrm{P} \times \mathrm{L} 16<36 \mathrm{~cm}$
d) $4=\mathrm{P} \times \mathrm{L} 36<80 \mathrm{~cm}$
e) $5=\mathrm{P} \times \mathrm{L}>80 \mathrm{~cm}$

2. Kedalaman luka
a) $1=$ Stage 1 ( kulit berwarna merah, belum tampak adanya lapisan epidermis yang hilang )
b) $2=$ stage 2 ( hilangnya lapisan epidermis / lecet sampai batas dermis paling atas )
c) $3=$ stage 3 ( rusaknya lapisan dermis bagian bawah hingga lapisan subkutan )
d) $4=$ stage 4 ( rusaknya lapisan subkutan hingga otot dan tulang )
e) $5=$ necrosis wound

3. Tepi luka
a) $1=$ samar tidak jelas terlihat
b) $2=$ batas tepi terlihat, menyatu dengan luka
c) $3=$ jelas, tidak menyatu dengan dasar luka
d) $4=$ jelas, menyatu dengan dasar luka, tebal
e) $5=$ jelas, fibrotik, parut tebal / hyperkeratinik

4. GOA
a) $1=$ tidak ada
b) 2 = goa $<2 \mathrm{~cm}$ diarea manapun
c) $3=$ goa $2-4 \mathrm{~cm}<50 \%$ pinggir luka
d) $4=$ goa $2-4 \mathrm{~cm}>50 \%$ pinggir luka
e) $5=$ goa $>4 \mathrm{~cm}$ diarea manapun

5. Tipe jaringan nekrosis
a) $1=$ tidak ada
b) 2 = putih abu abu jaringan mati atau slough yang lengket (mudah dihilangkan )
c) $3=$ slough mudah dihilangkan 
d) 4 = lengket lembut dan ada jaringan parut palsu berwarna hitam ( black eschar )

e) $5=$ lengket berbatas tegas, keras dan ada black eschar

6. Jumlah jaringan nekrosis
a) $1=$ tidak tampak
b) $2=<25 \%$ dari dasar luka
c) $3=25 \%-50 \%$ dari dasar luka
d) $4=>50 \%$ hingga $<75 \%$ dari dasar luka
e) $5=75 \%$ hingga $100 \%$ dari dasar luka

7. Tipe eksudat
a) 1 = tidak tampak
b) 2 = bloody (berdarah)
c) $3=$ serosanguineous (berdarah dengan plasma darah)
d) $4=$ serous (bening)
e) $5=$ purulent (pus /nanah)

8. Jumlah eksudat
a) $1=$ kering
b) $2=$ basah / lembab
c) $3=$ sedikit
d) $4=$ sedang
e) $5=$ banyak

9. Warna sekitar luka
a) $1=$ pink atau normal
b) $2=$ merah terang jika ditekan
c) $3=$ putih atau pucat / hipopigmentasi
d) $4=$ merah gelap / abu abu
e) $5=$ hitam / hyperpigmentasi

10. Jaringan yang edema
a) $1=$ no swelling / edema
b) $2=$ non pitting edema kurang dari $4 \mathrm{~mm}$ disekitar luka
c) $3=$ nonpitting edema lebih dari $4 \mathrm{~mm}$ disekitar luka
d) $4=$ pitting edema kurang dari $4 \mathrm{~mm}$ disekitar luka
e) $5=$ krepitasi atau pitting edema $>4 \mathrm{~mm}$

11. Pengeras jaringan tepi
a) $1=$ tidak ada
b) = pengerasan $<2 \mathrm{~cm}$ disebagian kecil sekitar luka
c) $=$ pengerasan $2-4 \mathrm{~cm}$ menyebar
d) = pengerasan $2-4 \mathrm{~cm}$ menyebar $>/=50 \%$ di tepi luka
e) = pengerasan $>4 \mathrm{~cm}$ diseluruh tepi luka

12. Jaringan granulasi
a) $1=$ kulit utuh atau stage
b) $2=$ terang $100 \%$ jaringan granulasi
c) $3=$ terang $50 \%$ jaringan granulasi
d) $4=$ granulasi $25 \%$
e) $5=$ tidak ada jaringan granulasi

13. Epitelisasi
a) $1=100 \%$ epitelisasi
b) $2=75 \%-100 \%$ epitelisasi
c) $3=50 \%-75 \%$ epitelisasi
d) $4=25 \%-50 \%$ epitelisasi
e) $5=<25 \%$ epitelisasi 
Hasil pengamatan proses penyembuhan luka dekubitus secara makroskopis meliputi fase inflamasi, fase proliferasi, dan fase maturasi atau di lihat dari ukuran luka, warna luka, adanya pus/eksudat luka serta dilihat dari nilai pre dan post test. ${ }^{13}$ Penelitian ini menggunakan variabel independen yaitu pemberian gel lidah buaya serta variabel dependen adalah proses penyembuhan luka dekubitus menggunakan skala ordinal. Berdasarkan variabel serta skala yang digunakan, maka penelitian ini menggunakan uji normalitas untuk melihat residual data normal atau tidak normal, dan untuk membuktikan ada atau tidak adanya pengaruh gel lidah buaya terhadap kesembuhan luka dekubitus maka dilakukan uji Mann Whitney, dengan nilai kepercayaan $95 \%(\alpha=0,05)$. Setelah mendapatkan hasil, selanjutnya $\mathrm{P}$ value dibandingkan dengan $\alpha=0,05$ untuk menentukan adakah hubungan antara variabel independen dan variabel dependen yang di teliti.

\section{HASIL DAN PEMBAHASAN}

Penelitian ini di lakukan di Desa Tanjung Rejo Kecamatan Percut Sei Tuan, Kabupaten Deli Serdang. Pengambilan data dilakukan sejak bulan Juli sampai Oktober tahun 2021 dengan jumlah sampel 10 orang yang terbagi dalam dua kelompok yaitu kelompok kontrol dan kelompok eksperimen (perlakuan). Berikut penjelasan dari hasil penelitian yang di lakukan peneliti di desa Tanjung Rejo Kecamatan Percut Sei Tuan, Deli Serdang:

Berdasarkan tabel di atas menunjukkan bahwa dari jenis kelamin responden, pada kelompok eksperimen persentase responden lebih banyak berjenis kelamin perempuan yaitu sebanyak 3 orang (30\%) dibandingkan responden laki - laki sebanyak 2 orang (20\%). Demikian pula pada kelompok kontrol, persentase responden lebih banyak berjenis kelamin perempuan sebanyak 3 orang (30\%) dibandingkan responden berjenis kelamin laki - laki sebanyak 2 orang (20\%). Usia responden, pada kelompok eksperimen persentase responden lebih banyak berusia 53-57 yaitu sebanyak 4 orang (40\%), dan pada kelompok kontrol responden yang berusia 53-57 sebanyak 4 orang (40\%).

Berdasarkan tabel di atas dapat kita ketahui bahwa kategori proses penyembuhan luka pada kelompok perlakuan tergolong cepat sebanyak 5 responden dengan persentase (100\%). Kategori proses penyembuhan luka pada kelompok kontrol di atas dapat di ketahui bahwa penyembuhan luka menggunakan $\mathrm{NaCl} 0,9 \%$ termasuk kategori sedang $80 \%$, lambat $20 \%$.

Proses penyembuhan luka dekubitus menggunakan gel lidah buaya (100\%) termasuk kategori cepat dengan memasuki proses penyembuhan luka fase maturasi di minggu ke 3-4, dengan tanda - tanda luka kering serta tidak ada jaringan parut. Sementara dengan pemberian larutan $\mathrm{NaCl} 0,9 \%(80 \%)$ termasuk kategori sedang dengan melampaui fase inflamasi dan fase poliferasi sedangkan fase maturasi belum terjadi sampai minggu ke -4 , dan (20\%) termasuk kategori lambat.

Berdasarkan tabel di atas menunjukkan bahwa skor hasil pengkajian luka responden sebelum diberikan perlakuan menggunakan gel lidah buaya di dapatkan rata - rata 32,8, sedangkan setelah diberikan perlakuan menggunakan gel lidah buaya didapatkan rata-rata 13,2. Selain itu dari ke-5 responden mengalami penurunan skor (terjadi peningkatan status luka), serta di dapatkan nilai rata-rata selisih dari pre dan post sebesar 19,6.

Berdasarkan tabel di atas menunjukkan bahwa skor hasil pengkajian luka responden sebelum diberikan pengobatan menggunakan larutan $\mathrm{NaCl} 0,9 \%$ di dapatkan rata - rata 26,2, sedangkan setelah diberikan pengobatan menggunakan larutan $\mathrm{NaCl} 0,9 \%$ didapatkan rata - rata 25,8. Selain itu dari 5 responden 4 mengalami penurunan skor (terjadi peningkatan status luka), sedangkan 1 responden mengalami peningkatan skor (terjadi penurunan status luka), serta di dapatkan nilai rata - rata selisih dari pre dan post sebesar 0,4 . 
Berdasarkan hasil uji normalitas diketahui nilai signifikasi $0,005<0,05$, maka dapat di simpulkan bahwa nilai residual berdistribusi tidak normal, sehingga di perlukan uji Mann Whitney.

Berdasarkan output uji Mann Whitney diketahui bahwa nilai Asymp. Sig. (2-tailed) sebesar 0,008 $<0,05$ atau $\mathrm{P}$ value $0,008<\alpha(\alpha=0,05)$ maka dapat di simpulkan bahwa ada perbedaan antara kelompok kontrol dengan kelompok perlakuan. Karena ada perbedaan yang signifikan maka dapat di katakan bahwa ada pengaruh pemberian gel lidah buaya (aloe vera) terhadap proses penyembuhan luka dekubitus.

\section{Identifikasi proses penyembuhan luka dekubitus menggunakan gel lidah buaya}

Berdasarkan hasil penelitian pada luka dekubitus dengan menggunakan gel lidah buaya (kelompok perlakuan) yang di observasi selama 4 minggu menunjukkan proses penyembuhan luka pada fase inflamasi rata-rata berakhir pada minggu ke 1 . Sekitar 2 dari 5 sampel kelompok perlakuan mengalami masa fase inflamasi lebih cepat di banding dengan 3 sampel lainnya. Tujuan utama dari fase ini adalah menghentikan perdarahan, mencegah terjadinya infeksi, dan menyingkirkan jaringan nekrosis serta benda asing dan bakteri yang timbul.

Perawatan luka menggunakan obat herbal bisa menjadi salah satu alternatif untuk proses penyembuhan luka, salah satu tanaman obat yang dapat digunakan untuk proses penyembuhan luka yaitu gel lidah buaya yang memiliki kandungan yang bersifat anti - inflamatori.

Hasil penelitian menunjukkan bahwa fase poliferasi pada kelompok perlakuan terjadi di minggu kedua, 2 dari 5 sampel mengalami proses fase poliferasi di minggu pertama, dan 3 dari 5 sampel mengalami proses fase poliferasi di minggu kedua. Pada fase poliferasi biasanya terjadi dalam waktu 4-24 hari di tandai dengan munculnya pembuluh darah baru sebagai hasil rekontruksi. ${ }^{12}$ Aloe vera dapat menguatkan sel dan jaringan; menjaga kesehatan; memperlambat penuaaan dini; meningkatkan metabolisme tubuh; membantu menyembuhkan dan menguatkan fungsi-fungsi tubuh; mengeluarkan bahan kimia beracun; dapat digunakan untuk mengatasi luka akibat sinar X dan luka bakar akibat radiasi sinar radium. Gel Aloe vera mengandung glukomannan, yakni suatu bagian kelompok polisakarida dan bradikinase, yaitu suatu inhibitor protease, magnesium laktat, senyawa antiprostaglandin, serta anti-inflamatori. Kandungan gel aloe vera dapat berpengaruh bagi kesembuhan luka, dan pada teori di sebutkan bahwa pada fase poliferasi terjadi dalam waktu 3-24 hari sedangkan dengan pemberian gel lidah buaya (perlakuan) mengalami fase poliferasi yang cukup singkat yaitu antara minggu pertama hingga minggu kedua sekitar hari ke 5-14.

Kelompok perlakuan dengan pemberian gel lidah buaya mengalami fase maturasi sekitar 3 dari 5 sampel pada minggu ketiga dan 2 lainnya memasuki fase maturasi di minggu ke 4. Fase maturasi merupakan tahap akhir penyembuhan luka dan dapat memerlukan waktu lebih dari 1 tahun, bergantung pada jenis luka, kedalaman, dan lainnya. Maka dari itu berdasarkan teori yang telah di jelaskan sebelumnya dan hasil penelitian ini sejalan bahwa pemberian gel lidah buaya dapa mempercepat proses penyembuhan luka dekubitus.

\section{Identifikasi proses penyembuhan luka dekubitus menggunakan larutan $\mathrm{NaCl} \mathrm{0,9 \%}$}

Berdasarkan hasil penelitian pada luka dekubitus dengan menggunakan larutan $\mathrm{NaCl} 0,9 \%$ (kelompok kontrol) yang di observasi selama 4 minggu menunjukkan proses penyembuhan luka pada fase inflamasi rata-rata berakhir pada minggu ke-2. Sekitar 1 dari 5 sampel kelompok kontrol mengalami masa fase inflamasi hingga minggu ke 4. Luka adalah rusaknya struktur dan fungsi anatomis sehingga dalam proses penyembuhan luka melewati beberapa fase diantaranya fase inflamasi, fase inflamasi merupakan fase pertama dalam proses penutupan luka dan sering di sebut fase reaktif yang berlangsung sejak terjadinya luka sampai kira-kira hari kelima. ${ }^{12}$

Fase inflamasi yang terjadi pada kelompok kontrol (dengan pemberian larutan $\mathrm{NaCl} 0,9 \%$ ) seluruhnya mengalami fase inflamasi memanjang di karenakan pada kelompok kontrol tidak di berikan obat apapun hanya di bersihkan menggunakan larutan $\mathrm{NaCl} 0,9 \%$ yang dapat menekan proses inflamasi.

Fase poliferasi pada kelompok kontrol (dengan pemberian larutan $\mathrm{NaCl} \mathrm{0,9 \%} \mathrm{)} \mathrm{sekitar} 2$ dari 5 sampel terjadi pada minggu kedua sedangkan 2 lainnya terjadi di minggu ketiga dan 1 sampel lainnya belum memasuki fase poliferasi hingga minggu ke empat. Fase poliferasi di tandai dengan munculnya pembuluh 
darah baru sebagai hasil rekontruksi. Aktifitas utama selama fase ini adalah mengisi luka dengan jaringan penyambung atau jaringan granulasi yang baru dan menutup bagian atas luka dengan epitelisasi, proses ini baru terhenti ketika sel epitel saling menyentuh dan menutup seluruh permukaan luka. ${ }^{12}$

Berdasarka fakta dan teori yang ada, peneliti berpendapat bahwa pada fase poliferasi kelompok kontrol (pemberian larutan $\mathrm{NaCl} 0,9 \%$ ) belum di ketahui sampai berapa lama fase poliferasi terhenti karena peneliti membatasi waktu observasi proses penyembuhan luka yaitu selama 4 minggu atau kira - kira 30 hari, fase poliferasi pada kelompok kontrol juga berpotensi lebih dari rentang waktu normal karena pada kelompok kontrol mengalami proses fase inflamasi memanjang.

Seluruhnya atau 5 sampel kelompok kontrol dengan pemberian larutan $\mathrm{NaCl}$ 0,9\% yang di observasi selama 4 minggu belum mengalami fase maturasi, fase maturasi dapat terjadi lebih dari 1 tahun tergantung pada kedalaman dan luas luka, yangmana fase maturasi pada kelompok control dapat berlangsung lebih lama karena tidak di berikan apapun yang dapat mempercepat proses penyembuhan luka, akan tetapi tubuh mempunyai kemampuan penyembuhan luka secara alami karena proses penyembuhan luka juga di pengaruhi oleh banyak faktor diantaranya usia, nutrisi, infeksi dan hipoksia.

\section{Analisis pengaruh pemberian gel lidah buaya terhadap proses penyembuhan luka dekubitus}

Hasil penelitian menunjukkan bahwa ada pengaruh pemberian gel lidah buaya terhadap kesembuhan luka dekubitus. Fakta ini di perkuat dengan hasil uji statistik Mann Whitney yang menunjukkan $\mathrm{P}$ value $0,008<\alpha(\alpha=0,05)$. Pada pemberian gel lidah buaya (kelompok perlakuan) seluruhnya 5 dari 5 sampel atau $100 \%$ dengan pemberian gel lidah buaya termasuk kategori cepat dengan fase maturasi terjadi di minggu ke $3-4$, sementara dengan pemberian larutan $\mathrm{NaCl}$ 0,9\% (kelompok kontrol) 4 dari 5 sampel termasuk kategori sedang dan 1 lainnya termasuk kategori lambat dengan kriteria melewati fase inflamasi dan poliferasi sedangkan untuk fase maturasi belum terjadi hingga minggu ke 4 .

Aloe vera mengandung glukomanan sebagai pendorong pertumbuhan sel-sel yang rusak karena luka dan mengecilkan jaringan sel/dengan diciutkan dan didorongnya pertumbuhan sel baru, sel-sel yang rusak cepat sembuh, asam-asam amino esensial dan non-esensial, enzim oksidase, katalase, lipase, dan protease. Enzim yang terakhir ini membantu memecahkan jaringan kulit yang sakit karena rusak dan membantu memecah bakteri, sehingga gel lidah buaya bersifat antibiotik, sekaligus meredam rasa sakit. Sementara itu, asam amino berfungsi menyusun protein pengganti sel yang rusak. ${ }^{12}$

Kandungan kimia dan zat aktif yang tekandung dalam gel lidah buaya efektif dalam penyembuhan luka terbukti pada kelompok perlakuan (dengan pemberian gel lidah buaya) seluruhnya termasuk kategori cepat dengan memasuki fase maturasi di minggu ke 3-4 sementara pada kelompok kontrol (dengan pemberian larutan $\mathrm{NaCl}$ 0,9\%) belum mengalami fase maturasi sampai minggu ke-4. Perbedaan karakteristik luka juga terlihat jelas, pada kelompok perlakuan tiap minggunya luka mengalami proses penyembuhan baik dari kedalaman, luas, warna dan lainnya. Sedangkan pada kelompok kontrol ada beberapa sampel yang lukanya tidak mengalami perubahan sehingga berdampak pada fase inflamasi memanjang dan berefek pada proses penyembuhan luka yang kemungkinan besar lebih dari waktu normal. Gel lidah buaya dapat di jadikan intervensi alternatif di kalangan masyarakat maupun tenaga kesehatan yang dapat di manfaatkan dalam proses penyembuhan luka dekubitus di lihat dari segi pengolahan yang terbilang cukup mudah.

\section{KESIMPULAN}

Berdasarkan uji statistik nilai pretest dan postest pada luka dekubitus yang telah di berikan perlakuan dengan gel lidah buaya, di dapatkan kesimpulan bahwa pemberian gel lidah buaya efektif pada perawatan luka dekubitus. Sedangkan hasil uji statistik pretest dan postest pada luka dekubitus yang telah di berikan perlakuan dengan larutan $\mathrm{NaCl} 0,9 \%$, di dapatkan kesimpulan bahwa pemberian larutan $\mathrm{NaCl} 0,9 \%$ tidak efektif pada perawatan luka dekubitus.

Selanjutnya uji Mann Whitney yang di lakukan untuk mengetahui perbedaan efektivitas antara pemberian gel lidah buaya dengan pemberian larutan $\mathrm{NaCl} 0,9 \%$, di dapatkan hasil bahwa ada perbedaan pengaruh yang signifikan antara pemberian gel lidah buaya dengan larutan $\mathrm{NaCl} 0,9 \%$, maka dapat 
disimpulkan terdapat perbedaan yang signifikan pemberian gel lidah buaya (aloe vera) terhadap proses penyembuhan luka dekubitus.

\section{UCAPAN TERIMAKASIH}

Terima kasih yang tak terhingga kepada Kepala Desa Tanjung Rejo serta jajarannya, masyarakat desa Tanjung Rejo dan semua pihak terkait yang telah berpartisipasi pada kegiatan ini.

\section{DAFTAR PUSTAKA}

1. Mamoto N, Gessal J. Rehabilitasi Medik Pada Pasien Geriatri Ulkus Decubitus. J Med dan Rehabil. 2018;1(1).

2. Novyana RM, Susianti S. Lidah Buaya (Aloe vera) untuk Penyembuhan Luka. J Major. 2016;5(4):149-153.

3. Budiyanto MAK. Efek Ekstrak Lidah Buaya (Aloe Vera) Terhadap Diameter Penyembuhan Luka Decubitus Pada Tikus Putih. Farmasains J Farm Dan Ilmu Kesehat. 2011;1(2).

4. Widodo A. Uji Kepekaan Instrumen Pengkajian Risiko Dekubitus Dalam Mendeteksi Dini Risiko Kejadian Dekubitus Di RSIS. J Penelit Sains Teknol. 2007;8(1):39-54.

5. Taryono T. Efektivitas Pemberian Topikal Bawang Putih (Allium Sativum) Untuk Mempercepat Penyembuhan Luka Akut Terkontaminasi Pada Tikus Putih (Rattus norvegicus). (Studi Di Laboratorium STIKes Insan Cendekia Medika Jombang). Dissertasi. STIKES Insan Cendekia Medika. Published online 2017.

6. Herman A, Thalib S, Ningsih LW, Studi P, Akademi DK, Makassar K. Efektifitas Perawatan Luka Decubitus Dengan Metode Modern Dressing Terhadap Proses Penyembuhan Luka: Literatur Review. 2021;XI:37-44.

7. Fatonah S, Dewi R. Efektifitas Penggunaan Virgin Coconut Oil ( Vco ) Secara Topikal Untuk Mengatasi Luka Tekan ( Dekubitus ) Grade I Dan Ii. Published online 2006:264-270.

8. Atik N, R. JIA. PERBEDAAN EFEK PEMBERIAN TOPIKAL GEL LIDAH BUAYA (Aloe Vera) DENGAN SOLUSIO POVIDONE IODINE TERHADAP PENYEMBUHAN LUKA SAYAT PADA KULIT MENCIT ( Mus Musculus ). Maj Kedokt Bandung. 2009;41(2).

9. Oktaviani DJ, Widiyastuti S, Maharani DA, Amalia AN, Ishak AM, Zuhrotun A. Review: Bahan Alami Penyembuh Luka. Maj Farmasetika. 2019;4(3):45-56.

10. Nazir F, Zahari A, Anas E. Pengaruh Pemberian Gel Lidah Buaya ( Aloe vera ) Terhadap Jarak Pinggir Luka pada Tikus Wistar. J Kesehat Andalas. 2015;4(3):827-834.

11. Jaedun A. Metodologi Penelitian Eksperimen. In: In Service I Pelatihan Penulisan Artikel Ilmiah LPMP DI Yogyakarta. ; 2011.

12. Oryctolagus K, Sewta CA, Wuisan J. Uji Efek Ekstrak Daun Lidah Buaya ( Aloe Vera L .) Terhadap Penyembuhan Luka Insisi Kulit. 2015;3(April):1-7.

13. Syapitri H, Siregar LM, Ginting D. Metode Pencegahan Luka Decubitus Pada Pasien Bedrest Total Melalui Perawatan Kulit. Idea Nurs J. 2017;VIII(2):15-22. 

Lampiran

Tabel 1. Distribusi responden berdasarkan jenis kelamin dan usia

\begin{tabular}{lccc}
\hline Kelompok & & Frekuensi & Persentase \% \\
\hline Eksperimen & & & \\
Jenis Kelamin & Laki-Laki & 2 & $20 \%$ \\
& Perempuan & 3 & $30 \%$ \\
Usia & $48-52$ & - & - \\
& $53-57$ & 4 & $40 \%$ \\
& $58-62$ & 1 & $10 \%$ \\
\hline Kontrol & & & \\
Jenis Kelamin & Laki-Laki & 2 & $20 \%$ \\
\multirow{2}{*}{ Usia } & Perempuan & 3 & $30 \%$ \\
& $48-52$ & - & - \\
& $53-57$ & 4 & $40 \%$ \\
\hline
\end{tabular}

Tabel 2. Kategori proses penyembuhan luka dekubitus pada kelompok perlakuan dengan pemberian gel lidah buaya dan pada kelompok kontrol dengan pemberian larutan $\mathrm{NaCl} 0,9 \%$

\begin{tabular}{cccc}
\hline \multirow{3}{*}{ Kelompok } & Kategori proses & & \\
\hline Eksperimen & penyembuhan luka & Frekuensi & Persentase \% \\
& Cepat & 5 & $100 \%$ \\
\multirow{4}{*}{ Kontrol } & Sedang & 0 & 0 \\
& Lambat & 0 & 0 \\
& Cepat & 0 & 0 \\
& Sedang & 4 & $80 \%$ \\
& Lambat & 1 & $20 \%$ \\
\hline
\end{tabular}

Tabel 3. Distribusi hasil analisa pemberian Gel Lidah Buaya dan Larutan NaCl 0.9\% pada luka decubitus

\begin{tabular}{|c|c|c|c|c|c|}
\hline \multirow{3}{*}{ No } & \multirow{3}{*}{$\begin{array}{c}\text { Rekapitulasi proses } \\
\text { penyembuhan luka } \\
\text { dekubitus }\end{array}$} & \multicolumn{4}{|c|}{ Kelompok } \\
\hline & & \multicolumn{2}{|c|}{ Perlakuan } & \multicolumn{2}{|c|}{ Kontrol } \\
\hline & & Frekuensi & Persentase $\%$ & Frekuensi & Persentase \% \\
\hline 1. & Cepat & 5 & $100 \%$ & 0 & 0 \\
\hline 2. & Sedang & 0 & 0 & 4 & $80 \%$ \\
\hline 3. & Lambat & 0 & 0 & 1 & $20 \%$ \\
\hline & Total & 5 & $100 \%$ & 5 & $100 \%$ \\
\hline
\end{tabular}


Tabel 4. Hasil pengkajian sebelum dan sesudah di beri perlakuan pemberian gel lidah buaya

\begin{tabular}{cccc} 
No Responden & Pre & $\begin{array}{c}\text { Skor Hasil } \\
\text { Post }\end{array}$ & Selisih \\
\hline 1 & 31 & 13 & 18 \\
2 & 34 & 14 & 20 \\
3 & 31 & 13 & 18 \\
4 & 31 & 13 & 19 \\
5 & 37 & 13 & 23 \\
\hline Jumlah & 164 & 66 & 98 \\
Mean & 32,8 & 13,2 & 19,6 \\
\hline
\end{tabular}

Tabel 5. Hasil pengkajian sebelum dan sesudah diberikan perlakuan pemberian $\mathrm{NaCl} 0,9 \%$

\begin{tabular}{cccc}
\hline No Responden & Sre & $\begin{array}{c}\text { Skor Hasil } \\
\text { Post }\end{array}$ & Selisih \\
\hline 6 & 26 & 24 & 2 \\
7 & 29 & 33 & -4 \\
8 & 28 & 27 & 1 \\
9 & 22 & 21 & 1 \\
10 & 26 & 24 & 2 \\
\hline Jumlah & 131 & 129 & 2 \\
Mean & 26,2 & 25,8 & 0,4 \\
\hline
\end{tabular}

Tabel 6. Hasil Mann-Whitney Test

\begin{tabular}{lr}
\hline Mann-Whitney U &, 000 \\
\hline Wilcoxon W & 15,000 \\
\hline Z & $-2,635$ \\
\hline Asymp. Sig. (2-tailed) &, 008 \\
\hline Exact Sig. [2*(1-tailed Sig.)] &, $008^{\mathrm{b}}$ \\
\hline
\end{tabular}

a. Grouping Variable: Kelompok

b. Not corrected for ties. 